\title{
Rule 68 Offers of Judgment: The Practices and Opinions of Experienced Civil Rights and Employment Discrimination Attorneys
}

Thomas A. Eaton

University of Georgia School of Law, teaton@uga.edu

\section{Repository Citation}

Eaton, Thomas A., "Rule 68 Offers of Judgment: The Practices and Opinions of Experienced Civil Rights and Employment Discrimination Attorneys" (2007). Popular Media. 4.

https://digitalcommons.law.uga.edu/fac_pm/4

This Article is brought to you for free and open access by the Faculty Scholarship at Digital Commons @ University of Georgia School of Law. It has been accepted for inclusion in Popular Media by an authorized administrator of Digital Commons @ University of Georgia School of Law. Please share how you have benefited from this access For more information, please contact tstriepe@uga.edu. 


\section{Rule 68 offers of Judgment: \\ The practices and opinions of experienced civil rights and employment discrimination attorneys}

By Hosch Professor Thomas A. Eaton and Mercer University School of Law’s George Professor Harold S. Lewis Jr. Editor's Note: This is an abridged version of an article that will be published in a forthcoming issue of Federal Rules Decisions.

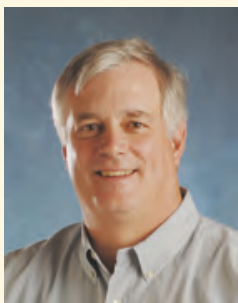

A

s structured by Rule 68 of the Federal Rules of Civil Procedure, offers of judgment are intended to encourage settlement but are widely thought to be ineffective in doing so. The primary explanation for this impotence is that Rule 68 does not provide enough of a carrot or stick to move the parties to the prompt resolution of their dispute.

In broad terms, offers of judgment impose a price on one party's refusal to accept a reasonable offer. Under the text of Federal Rule of Civil Procedure 68, that price is a forfeiture of the relatively modest "costs" described by 28 U.S.C. $\$ 1920^{1}$ that would otherwise be recoverable by a prevailing party, as well as payment of the defendant's post-offer costs of the same kind.

Significantly, the costs put in play by the bare text of Rule 68 do not include attorneys' fees and in most cases will even in the aggregate be so modest that they will not create a significant incentive for a defendant to make, or a plaintiff to be fearful of rejecting, an offer of judgment.

In light of the weak incentives, it is not surprising that Rule 68 has played only a minor role in federal civil litigation since its enactment in 1937.

There are, however, certain classes of claims in which Rule 68 has the potential to be a much greater influence on dispute resolution - claims under statutes that include attorneys' fees as part of recoverable costs.

In its 1985 opinion in Marek v. Chesny ${ }^{2}$, the Supreme Court melded the Rule 68 term "costs" with the phrase "fees as part of the costs" that appears in 42 U.S.C. $\$ 1988$, which codifies the Civil Rights Attorney's Fees Awards Act of 1976. That statute authorizes awards of attorneys' fees to plaintiffs who prevail in claims brought under certain civil rights statutes, as well as to the rare prevailing defendant that can demonstrate a plaintiff's claim was frivolous or without foundation.

Under Marek, a plaintiff who rejects a Rule 68 offer and prevails at trial for an amount not exceeding the offer forfeits not only the modest costs discussed above but also all post-offer attorneys' fees that a prevailing civil rights plaintiff would otherwise receive by virtue of a federal statute.

While a significant number of federal feeshifting statutes do not employ the "fees as part of costs" language upon which Marek relied, the great bulk of contemporary federal question litigation is founded on statutes that do award fees as part of costs.

Notably, this latter group includes litigation under most civil rights legislation, ${ }^{3}$ Title VII of the Civil Rights Act of $1964^{4}$ and a significant number of environmental statutes.

At the time

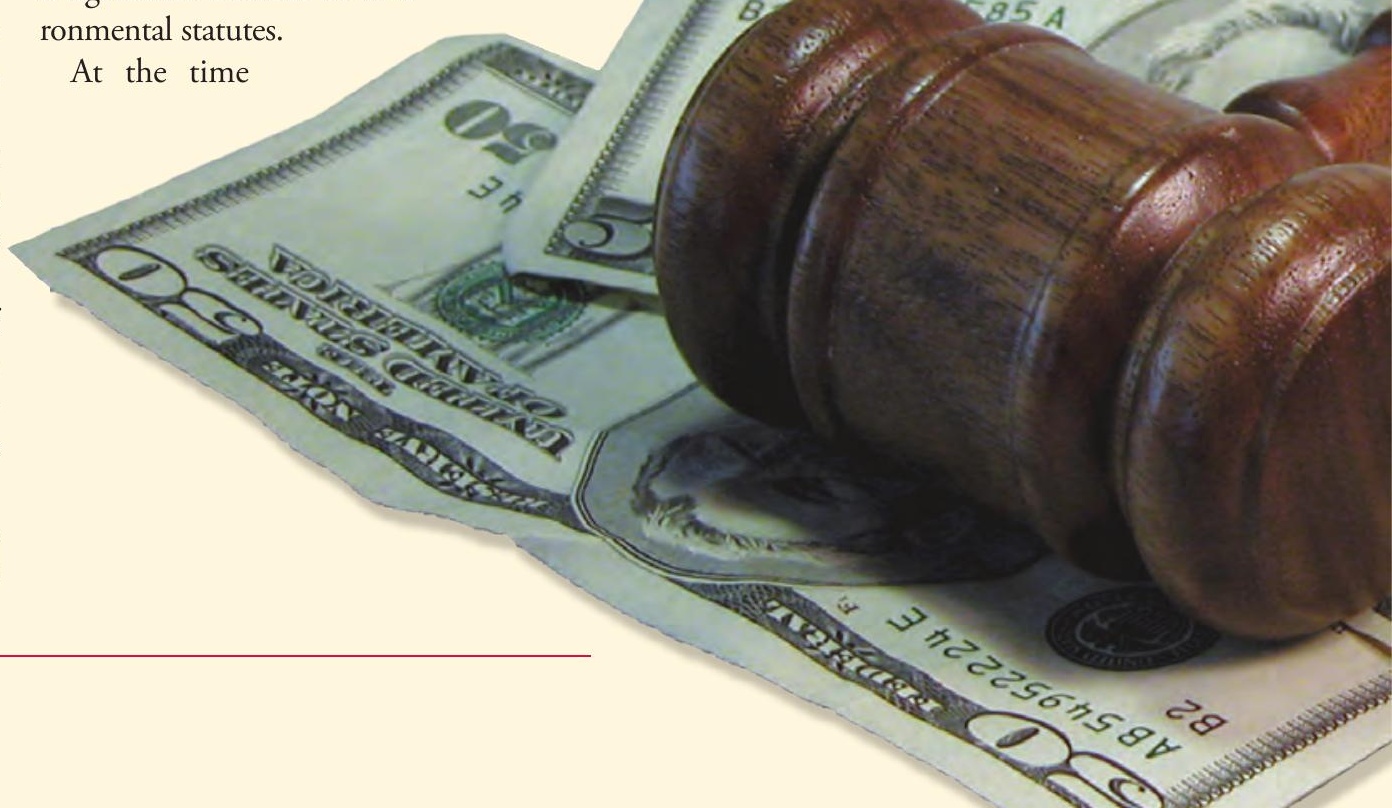

Marek was decided, many commentators feared Rule 68 would give civil rights defendants so much leverage that Rule 68 offers would effectively coerce premature and unfair settlements.

Specifically, it was speculated that defendants would routinely make early, low-ball offers of judgment; plaintiffs, fearful of forrecovery (attorneys' fees), would feel compelled to accept many such offers without having had the opportunity to conduct sufficient discovery to evaluate with care the probability and magnitude of success; and the federal policies underlying these fee-authorization statutes would be seriously undermined as a result.

For the most part, however, it appears that these concerns did not materialize. In the two decades following Marek,

there have been only occasional feiting what is often the largest part of their 
reported decisions construing Rule 68 .

In addition, anecdotal reports from both plaintiff and defense counsels whose practices are devoted to employment discrimination and civil rights confirm the rarity of Rule 68 offers.

Despite the widespread belief that Rule 68 has had little practical effect on civil litigation, there is a resurgence of interest in offers of judgment. States, including Georgia, have enacted new offers of judgment statutes, or modified existing ones, as part of civil litigation reform efforts. ${ }^{5}$

Academic literature abounds with doctrinal, theoretical, experimental and empirical scholarship that explores how offers of judgment statutes might be more effective in achieving the goal of bringing about the faster, less costly resolution of federal civil litigation without undue sacrifice of fairness to parties.

We were interested in learning why Rule 68 is not a more prominent feature of civil rights and employment discrimination litigation. Why is it not used more frequently in the very types of cases in which defendants have the greatest economic incentive to make offers and plaintiffs have the most to lose if they refuse them?

Our interest in Rule 68 is not driven by the belief that

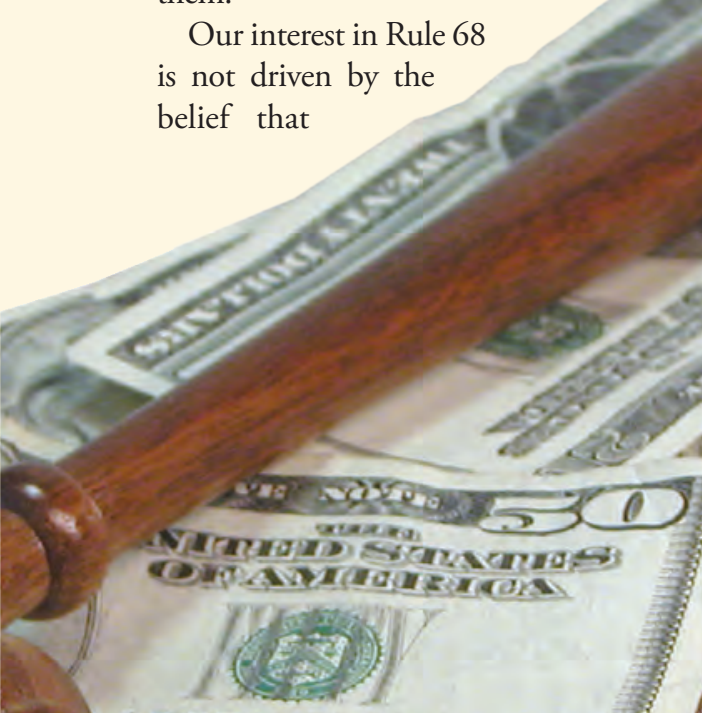

$A B>5163585 A$ +.4.

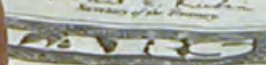
.

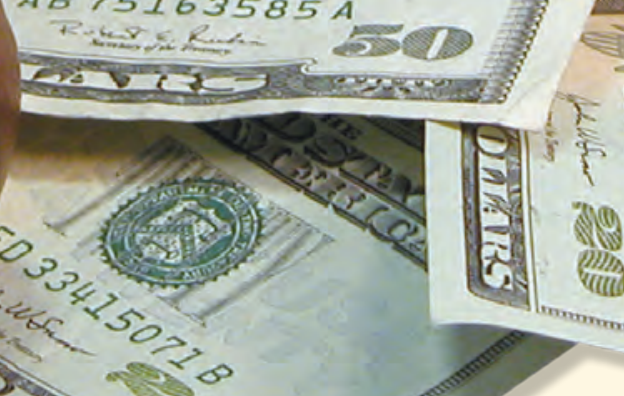

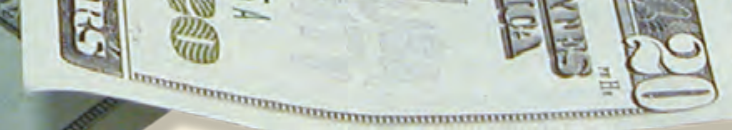

too many cases go to trial. Indeed, it appears the civil trial has become a notable rarity - by one respected account, more than 98 percent of federal civil litigation is resolved by means other than trials. ${ }^{6}$

Nevertheless, Rule 68 may harbor the potential to speed up the settlement process and thereby produce significant economic savings to the parties, with correlative savings to the courts and the taxpayers who fund them.

Our contribution to the policy discussion is to report the views of experienced practicing attorneys who decide on a daily basis whether to make or accept offers of judgment.

We conducted in-person, in-depth interviews with 64 experienced litigators who prosecute and defend civil rights and employment discrimination claims. This is the first such nationwide empirical inquiry into the incidence of practitioner use of Rule 68 in the federal fee-authorization cases where, after Marek, one would expect its use to be most common.

We interviewed cohorts of four attorneys in each of 16 cities. Each

\section{With some exception, Rule 68 offers are rarely made in federal civil rights and employment dis- crimination cases}

The first research question we explored was whether the anecdotes were true: is Rule 68 largely ignored? Our interviews confirmed that in federal districts throughout the United States, Rule 68 offers of judgment are rarely used in either employment discrimination or civil rights cases.

A New York City employment discrimination plaintiff attorney who had been in practice for 33 years reported he had received three offers in his practice experience - one every 11 years.

An employment discrimination defense lawyer in New Orleans said he had made 10-15 offers in 30 years of practice. That works out to one offer made every two or three years. 
A Chicago employment defense lawyer said he had not made any Rule 68 offers in the past five years.

An in-house corporate counsel, who supervises employment discrimination cases for one Fortune 500 company, said his client had not made an offer of judgment during the past decade.

On the civil rights side, one defense lawyer stated he had made no more than 10 offers over a 30-year career in which he and his firm have processed 10,000 cases on behalf of the state's largest city and various sheriff's departments.

Civil rights defense attorneys in Memphis and Houston, who between them had more than 40 years of experience, had never made a Rule 68 offer.

These stories tend to confirm the conventional wisdom regarding the infrequent use of Rule 68.

While the general rule is one of non-use or very infrequent use, there were some notable exceptions.

Civil rights defense lawyers in New York City, Minneapolis, Philadelphia, Oakland and the greater Seattle area report they now consider whether to make a Rule 68 offer as a routine part of initial case evaluations.

A civil rights defense lawyer in the Pacific Northwest reported he has made Rule 68 offers in 70 percent of his cases. No one else we interviewed came even close to that figure.

All the reports of systematic use of Rule 68 came from lawyers practicing civil rights defense, not employment discrimination defense. Thus, the lawyers reporting the greatest use of Rule 68 all represented public - not private - defendants.

Even in cities in which civil rights defendants make Rule 68 offers with some frequency, we found no evidence of similar use of Rule 68 in employment discrimination cases, where most defendants are private companies.
Why aren't more Rule 68 offers of judgment made in civil rights and employment discrimination cases?

There is no single answer to this question. However, several themes recurred throughout the interviews. A few of the more prominent themes include the following:

concerned about adverse publicity.

Some lawyers were concerned about more specific adverse consequences. For example, we were told by several civil rights defense lawyers that a police officer who has a judgment entered against him individually would have more difficulty securing a mortgage and face difficulties in career advancement.

Lawyers for public defendants, and to a lesser extent private defendants, also expressed a need to back up their team: "we're not going to make offers of judgment because it makes it look like we're not backing our police officers," or "we need to support the police" or "we need to support the supervisors in our company, especially when we do not think that they did anything wrong."

The term "judgment" was viewed by many attorneys as an admission that the alleged wrongdoing had occurred, while a "settlement" could be explained on grounds other than the merits.

\section{declarations of wrongdoing.}

- Hosch Professor Tom Eaton and George Professor Harold Lewis

2. Why make a Rule 68 offer when we are confident that we will ultimately win the case?

Many defense counsels explained they do not make frequent use of Rule 68 because they are confident

\section{Problems with the term "judgment"}

The most frequently voiced explanation for why Rule 68 is not used more often is that there are problems associated with the word "judgment."

Privately negotiated settlements typically include non-admission of liability clauses and confidentiality provisions. Judgments are more formal public declarations of wrongdoing.

Many defense lawyers reported their clients, both public and private, want to avoid making this formal declaration of wrongdoing.

Some defense counsels explained their clients would not want to make a public declaration of wrongdoing because doing so might encourage others to sue.

Other lawyers reported their clients were they will prevail on the merits, often at the summary judgment stage.

On its face, Rule 68 triggers a sanction only when the plaintiff receives a judgment for less than the amount of the offer. Thus, it provides no specific tangible reward to a defendant for having made an offer if the defendant then wins the case outright on the merits.

Interestingly, some employment discrimination defense lawyers who do not make Rule 68 offers in federal court said they do make offers under corresponding state rules where the state rules allow their clients to recover attorneys' fees from the plaintiff.

Thus, there appears to be some merit to the proposition that if court rules hold out to defendants the prospect of not just relief 
from paying a plaintiff's fees, but an affirmative award for their own fees, they might make more Rule 68 offers.

\section{3. "Not a penny for tribute"}

The reluctance to make a Rule 68 offer may be part of a broader, hardball litigation strategy.

Several defense lawyers commented their clients would rather pay thousands for defense and "not a penny for tribute." This suggests that clients would rather pay more money litigating than it would take to resolve the dispute under Rule 68.

Why would that be so? Discouraging the filing of other claims, avoiding adverse publicity, and supporting government and corporate officials whose actions are being challenged may all play a part.

One civil rights defense lawyer expressed the "not a penny for tribute" sentiment in terms of morality, saying that it was "just wrong" to spend a dollar of taxpayer money to pay a non-legally deserving plaintiff. That, in his view, is a misuse of public funds.

Of course a defendant adopting this stance may be just as averse to a privately negotiated settlement as to a resolution under Rule 68.

\section{Economic conflict of interests}

The fourth common theme is the specter of economic conflict between the defendant and defense counsel.

Since the primary leverage Rule 68 provides is the forfeiture of plaintiffs' post-offer attorneys' fees, the offer is more effective if made early in the litigation.

If a Rule 68 offer is made closer to trial (e.g., after the denial of a defense motion for summary judgment), a lesser amount of the plaintiff's attorneys' fees is at risk after the offer is rejected.

Most defense lawyers are paid on the basis of an hourly fee. There is a widespread suspicion among plaintiff lawyers that one reason more Rule 68 offers are not made early in the litigation is that defense lawyers wish to accrue a certain amount of fees before encouraging their clients to settle.

Most but not all of the plaintiff lawyers we interviewed subscribed to the belief that economic conflict between defendants and their lawyers partially accounts for the apparent underutilization of Rule 68.

Of course, no defense lawyer admitted to running up his own fees, but some acknowl- edged that there might be others who do.

Other defense lawyers expressed strong disagreement, even outrage, at this suggestion. They pointed out that market forces push them towards efficient resolution of disputes. Competition among the defense bar for clients is such that a lawyer who pads his hours will soon find his client represented by another attorney.

And even in single engagement cases where counsel does not expect to represent the client in future matters, there is often an insurance company that is paying the cost of defense.

The economic conflict theory is also called into question by the fact that many salaried government attorneys who do not stand to gain financially by increasing the number of hours devoted to resolving a dispute, nevertheless, also fail to recommend Rule 68 offers.

On the other hand, the only lawyers we found who did make Rule 68 offers with any degree of frequency were those representing public defendants. And they did so despite the bureaucratic obstacles of gaining settlement authority reported by some of those lawyers.

To some extent this finding may support the assumption that there is economic conflict between private, hourly paid defense lawyers and their clients.

\section{Problems with placing a value on a claim early in the litigation}

A few defense lawyers said they cannot accurately evaluate a case sufficiently early in the litigation to make Rule 68 an attractive inducement to resolve the dispute.

One defense lawyer claimed he needed 18 months of discovery before he could ethically evaluate what a case was worth.

This problem is compounded by defense uncertainty regarding the amount of plaintiff pre-offer attorneys' fees.

The current Rule makes the amount of those fees critical to calculating whether a plaintiff's ultimate judgment exceeds the defendant's offer, yet it does not require a plaintiff to disclose those fees to facilitate fully informed offers.

Very few of our interviewees deemed ordinary case valuation to be a significant problem.

Plaintiff and defense lawyers in both civil rights and employment discrimination prac- tices overwhelmingly agreed a defense lawyer can value a case in terms of liability and damages fairly early on in the litigation - generally within four to six months after the action commences.

Further, most defense lawyers thought they could either estimate the plaintiff's preoffer fees by considering what the defense fees were at that point in the case; or by evaluating how well they thought the plaintiff was prepared at that stage; or simply by asking the plaintiff's counsel directly for this information.

However, several defense lawyers expressed the view that plaintiffs' fees often do not correspond to defense fees and that plaintiff counsels generally refuse to provide this information when requested.

\section{Attorneys' reactions to reform proposals \\ Soften terminology from "judgment" to "settlement/agreement"}

The first proposal was simply a terminology change. Instead of an offer of "judgment," amend the Rule 68 to authorize an offer of "settlement" or "agreement" or "compromise," the language used in rules in several states.

In a similar vein, we inquired about having the Rule expressly authorize the defendant to include in the offer a nonadmission of liability clause, which some of our lawyers considered logically inconsistent with a "judgment."

There was almost universal support among our plaintiff and defense lawyer respondents for softening the Rule's terminology from offer of "judgment" to offer of "settlement" or "agreement."

All who expressed a view on the issue agreed the change had the potential to increase defendants' use of the Rule.

A small number of plaintiff lawyers opposed altering the terminology fearing that an increased use of Rule 68 would do their clients more harm (e.g., low-ball offers that might coerce early resolution) than good (earlier payment of a reasonable sum).

Others expressed concern that the term "settlement" undermined the public vindication of the plaintiff and condemnation of the defendant implicit in the latter's confession of a "judgment." 
Fundamentally reformulating the Rule to be two-way, so plaintiffs as well as defendants could initiate the offer process

Although several states, including Georgia, empower plaintiffs to make Rule 68 offers, the current Federal Rule allows only defendants to do so.

Initially we asked the lawyers about their general attitude, without getting into the details, about allowing plaintiffs, as well as defendants, to initiate the offer.

That is, for the first time, federal court plaintiffs would have the option of submitting an offer (really, a demand) of judgment or settlement that would put defendants at risk for some sanction, probably a fee multiplier, beyond the damages and fee liability defendants currently incur if they are found liable in an action under a federal fee-recovery statute.

Plaintiff counsels overwhelmingly and strongly supported this change.

If the Rule were made two-way, they said, plaintiffs would use it early and routinely as a way of dynamiting earlier offers out of recalcitrant defendants, particularly those whose liability was backed by an insurer.

Plaintiff counsels further speculated that defendants would likely respond with their own early counter-offers of judgment.

Plaintiff lawyers also asserted that a plaintiff's offer (demand) followed by a defendant's offer would establish a more reasonable range for settlement at an earlier time in the litigation than in ordinary settlement negotiations.

This assertion was premised on the belief that Rule 68 offers are of potential value to offerors only if they represent predictions of trial outcomes that are credible to offerees.

Many defense counsels were strongly opposed to empowering plaintiffs to make a Rule 68 offer, although a significant number were either moderately or strongly supportive. We should not, however, underestimate the intensity of the opposition on the part of many defense lawyers.

In general, they reasoned that defendants who lost at trial were already liable to pay 100 percent of the plaintiffs' fees and that any additional sanction was excessive. Or they pointed out that defendants who make offers and plaintiffs who make demands are not similarly situated, in that offers are underwritten by a defendant's real resources while demands cost plaintiffs nothing.

\section{A summary of attorneys' reactions to two-way reform proposals}

We presented the attorneys with a number of specific proposals.

These had two primary variables: the sanction imposed on the party rejecting the Rule 68 offer and defining when the sanction would be triggered.

Determining the appropriate sanction is quite tricky.

Clearly, the current Rule 68 sanctions do not induce civil rights and employment discrimination defendants to make many Rule 68 offers.

What sort of additional sanctions might prompt defendants to make more Rule 68 offers (e.g., requiring plaintiffs who did not improve on the offer at trial to pay some multiple of defendants' costs or even defendants' post-offer attorneys' fees)?

On the other hand, given that civil rights and employment discrimination plaintiffs who prevail at trial already are awarded attorneys' fees, what additional sanction might be awarded to a plaintiff when a defendant who rejects the plaintiff's Rule 68 offer and does not improve on the offer at trial (e.g., an enhancement of attorneys' fees)? And what circumstances would trigger these sanctions?

One set of proposals suggested creating additional "pressure" by requiring the offeree to beat the offer by a certain percentage (say, 15 or 25 percent) to avoid a sanction. Other proposals incorporated a "cushion" by denying sanctions if the outcome at trial fell within some specified percentage of the offer (again, say, 15 or 25 percent).

None of the specific proposals received uniform support.

Yet opposition to particular proposals may have obscured somewhat greater support by both plaintiff and defense lawyers for the general concept of some kind of two-way rule.

More than a few lawyers who objected to specific details of a proposed model nevertheless embraced the broad suppositions underlying a two-way Rule 68.

These suppositions are that defense lawyers who might not now counsel their clients to consider the Rule would routinely and quickly do so if their clients were to receive a plaintiff's offer of judgment (demand) under a two-way regime.

There would then be two offers (really an offer and a demand) on the table. If each was made thoughtfully, those offers might be pegged at a somewhat more realistic level than the customarily extreme initial demands and responses in standard positional bargaining.

This is because the benefits under the Rule for a plaintiff offeror would not be triggered unless she could beat her own offer after trial by at least a penny, or perhaps by a modest percentage; and the benefits for a defendant offeror would not be triggered if the plaintiff could exceed or come close to that offer within the same margins.

Further, those somewhat more realistic demands and offers would presumably be made earlier than the opening salvos in ordinary private settlement negotiations.

Unlike the defendant, who has sole control over initiation of Rule 68 today, the plaintiff and plaintiff's lawyer are typically desirous of resolving litigation and being compensated as soon as possible. They, therefore, have every incentive to consider making a Rule 68 offer quickly.

Finally, the Rule's 10-day deadline for acceptance or rejection of an offer/demand, often 30 days in state practice, might result in both sides focusing on settlement and, mindful of probable trial outcomes, doing so earlier than in ordinary bargaining uninfluenced by the Rule.

Several respondents offered an opinion about whether this "realism" dynamic is implicit in a two-way rule and would speed the pace of settlements.

Civil rights plaintiff lawyers told us, at least in theory, a two-way rule would lead to earlier resolutions and would not have any more negative effects on their clients than the current Rule.

Civil rights defense lawyers responded more diversely on the general utility of a two-way rule. Some opined it would not have much effect because plaintiffs' typical demands are (and implicitly would remain) outrageous.

Others agreed that a two-way approach would elicit early, more reasonable plaintiff demands and would encourage earlier resolution of conflicts by providing pressure well before trial is imminent.

The most widespread enthusiasm for a 
two-way rule was found among our plaintiff employment discrimination lawyers.

The degree of support for a two-way rule among those lawyers was somewhat surprising given the view held by many that the threat of increased costs sanctions on their clients might well deter the initiation or continued prosecution of viable claims.

Few employment discrimination defense counsels - the lawyer group probably most threatened economically by the successful use of the Rule - opined on a two-way rule, but most who did were, perhaps surprisingly, somewhat supportive, at least in the abstract.

\section{Dilemmas for the amendment process}

History suggests that would-be reformers of Rule 68 should approach the task with considerable caution.

Prior efforts to modify Federal Rule 68 have failed, and the prospects for success depend importantly on securing a consensus from both sides of the bar.

The core challenge is to devise a set of sanctions, triggered under

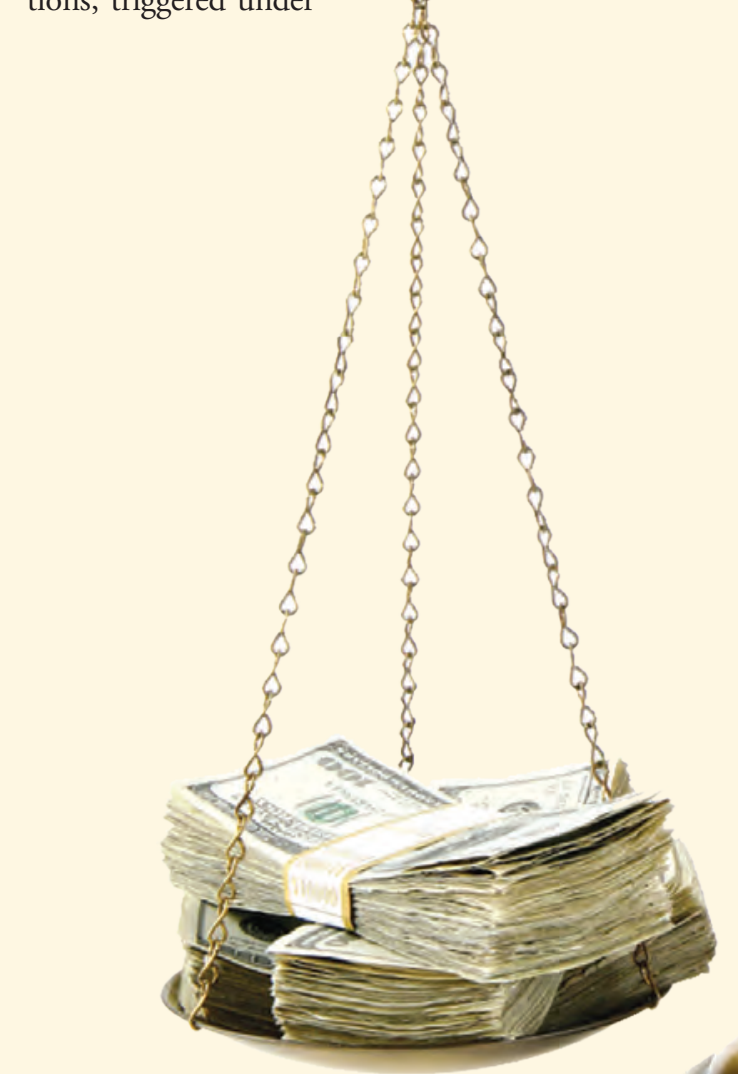

circumstances, that both sides view as sufficient to induce the parties to make early offers, but not so great as to unfairly coerce parties to forego their legitimate rights to pursue and defend civil rights and employment discrimination claims.

Striking this balance in a way that both plaintiff and defense attorneys deem palatable should prove to be quite difficult.

\section{End Notes}

${ }^{1}$ These costs include fees charged for the clerk, marshal, court reporter, printing, witness, copying, docketing and court appointed experts listed in 28 U.S.C. $\$ 1920$. 2473 U.S. 1 (1985).

${ }^{3}$ Governed by the Civil Rights Attorney's Fees Awards
Act of 1976, 42 U.S.C. $\$ 1988(b)$.

${ }^{4}$ See 42 U.S.C. $\$ 2000 e-5(k)$ (2005). But the Age Discrimination in Employment Act (ADEA), a parallel national employment discrimination statute, awards fees in addition to, rather than as part of, costs. 29 U.S.C. $\$ 626(b)$ (2005). Thus, under the Marek reasoning, if a Rule 68 offer is triggered in an action under $A D E A$, the Rule would not force the plaintiff to forfeit postoffer attorneys' fees, only post-offer Section 1920 "costs." Marek, 473 U.S. at 25-27 n.36. The exclusion of claims under ADEA from the principal consequence of Rule 68 offers will presumably assume increasing importance with the graying of the American workforce.

${ }^{5}$ E.g., Official Code of Georgia Annotated \$ 9-11-68 (2006); Vernon's Texas Statutes and Codes Annotated \$ 42.004 (2004). For a discussion of state offers of judgment rules and the lessons they may provide for amending Federal Rule 68, see Lesley S. Bonney et. al., Rule 68: Awakening a Sleeping Giant, 65 Geo. Wash. L. Rev 379 (1997); Anna Aven Sumner, Note, Is the Gummy Rule of Today Truly Better Than the Toothy Rule of Tomorrow? How Federal Rule 68 Should Be Modified, 52 Duke L. J. 1055 (2003).

${ }^{6}$ Marc Galanter, The Hundred-Year Decline of Trials and the Thirty Years War, 57 Stan. L. Rev. 1255, 1257 (2005) (in 2003, only 1.7 percent of civil terminations occurred during or after federal trial); Marc Galanter, A World Without Trials, 2006 J. Disp. Res. 7 (in 1962, federal civil trials accounted for 11.5 percent of case terminations; in 2004, civil trials made up 1.7 percent of terminations).

${ }^{7}$ Delta Air Lines, Inc. v. August, 450 U.S. 346 (1981).

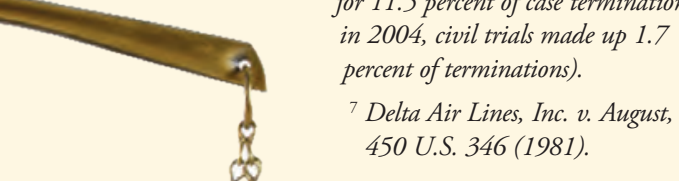

